\title{
1. Introduction: why study the transatlantic history of administrative ideas?
}

Comparative administrative research and theory usually considers German, French and US Public Administration as independent units of analysis that each have their own specific intellectual traditions. ${ }^{1}$ In the sense of inherited ideas surrounding the nature and history of government in a particular national context, intellectual traditions are commonly regarded as cultural variations, historical legacies or path dependencies at the macro-level (Bevir et al. 2003, 6; Yesilkagit 2010, 148). In this context, the developments of German, French and US Public Administration serve as classic examples of Continental European and Anglo-American intellectual traditions (Kickert and Stillman 1999; Painter and Peters 2010; Rohr 1992; Rutgers 2001). Richard Stillman (1997, 337), for instance, holds that administrative research and theory has always taken fundamentally different forms in Continental Europe and the USA, which is why 'neither side quite knows how to make sense out of the other's administrative sciences.' When comparing traditions of administrative thought, the focus is usually on differences and incremental change rather than on similarities and change that is the result of mutual perceptions and fertilizations among Continental European and US scholars. Public Administration is therefore largely perceived as specifically German, French and American or Germanic, Napoleonic and Anglo-American.

While Public Administration traditions are highly useful as conceptual maps, it is debatable as to what degree such schematic models are empirically valid. Conducting deductive comparative research against the background of self-referential paths may have the effect of partly prefiguring the results. We therefore introduce the transfer-of-ideas approach in order to address the empirical substance of traditions analytically (Sager et al. 2012). Instead of 
providing center stage to parallel structural characteristics and processes within separate units of comparison, our approach focuses on the reinterpretation(s) resulting from the very transfer of ideas.

The transfer-of-ideas approach does not refrain from relying on intellectual traditions as clear-cut units of comparison. However, 'its inductive orientation aims to limit effects through an investigative mechanism in which the objects, categories, and analytical schemes are adjusted in the course of research' (Werner and Zimmermann 2006, 46). As a result, hybrid intellectual traditions, something that common sense may accept from the outset, no longer form a blind spot in comparative Public Administration. The analysis of the transfer of administrative ideas suggests that it is more realistic to interpret intellectual traditions as crossbreeds, instead of distinctively and uniquely German, French or US breeds. This book thus promises important methodological and theoretical implications for the further development of the comparative study of public administration.

Aside from a methodological and theoretical interest, our findings have direct practical relevance for current research on administrative and managerial reforms. At the present, the importance of transferring knowledge to prompt reform can hardly be overestimated. New Public Management (NPM) has until fairly recently dominated Public Administration (Raadschelders and Lee 2011) and its doctrines have massively influenced the design of reforms in political and administrative systems. The alleged universal applicability of these doctrines has drawn criticism from several directions, which has provided strong impetus for the development of innovative approaches, such as the Neo-Weberian State approach (for example, Eymeri-Douzans and Pierre 2011; Olsen 2006; Ongaro 2015; Pierre and Rothstein 2011; Pollitt and Bouckaert 2004), Public Value Management (for example, Beck Jørgensen and Rutgers, 2015; Bozeman 2007; Bryson et al. 2014; Moore 2014; Stoker 2006) and Neo-Progressivism (Lowery 1999). Thanks to the work of these scholars, we now know that the different degrees of successful administrative and managerial reforms depend on cultural, political and institutional contexts. However, the success of transferred concepts has often been seen as too low, which is due to their poor acceptance among recipients and their lack of adaptation 
to the established administrative practice. This corroborates the path-dependency hypothesis of historical institutionalism.

Our book demonstrates that the alleged universal applicability of administrative doctrines is not new. However, in contrast to the quite common observation that doctrines have a hard time traveling, we show that the transfer of knowledge from one context to the other has often led to disciplinary progress. In order to grasp this progress, we must pay close attention to how imported doctrines are appropriated and modified. By doing so, our analysis of the transfer of ideas gives way to a more optimistic stance. It shows that transfer occurs when foreign concepts are not directly applied but are rather first translated intellectually into the recipient's web of ideas and beliefs. We thereby contribute to the development of a perspective that is appropriate when analyzing the plethora of concrete challenges facing contemporary interdependent administrative and managerial systems. Our book furthermore encourages the self-reflection of the current approaches mentioned above by demonstrating their intellectual roots and theoretical underpinnings. In other words, our analysis provides the, at times lacking, background for these approaches in order to uncover anachronisms and the polysemy of the different concepts in use.

Finally, the book satisfies a historical interest: there are hardly any comprehensive studies on the overall development of Public Administration in Germany, France and the USA, and the few that exist do not focus on foreign influences. For example, the central questions driving German Public Administration have been explored cursorily by Werner Jann and Jörg Bogumil (Bogumil and Jann 2009; Jann 2011; 2009; 2003) and Wolfgang Seibel (1982, 1996), who acknowledged the influence of the US field of study, without analyzing it. As for French Public Administration, thirty years ago, Jacques Chevallier (1986) provided a chronology of its main currents. More recently, Renaud Payre (2006) and Pierre-Yves Saunier (2003) have drawn attention to the exchange of administrative ideas between France and the USA between World War I and World War II, especially among municipal administration scholars. An overview of socio-historical studies on French administrative knowledge and know-how is provided by Payre and Pollet (2013) in Eymeri-Douzans and Bouckaert's volume on French public administration (2013). Last but not least, several scholars hold that US Public Administration has a "poor understanding of its own 
history' (Luton 1999, 210; cf. Adams 1992, 368; Miewald 1994, 323-4; Raadschelders et al. 2000; Spicer 2004, 359). Given the lack of information on the development of public administration in these countries, there is consequently relatively little profound knowledge about the transfer of administrative ideas from Germany and France to the USA. In view of these knowledge gaps, we conduct a thorough empirical study on the basis of previously unexplored primary sources. We thereby aim to provide a concise history of Public Administration that does justice to both national idiosyncrasies and public administration in a world of globalized science. This sheds new light on administrative traditions, which have thus far been mainly studied from a theoretical perspective (see Table $1.1)$.

Table 1.1 Differences between the logic of tradition and the logic of transfer

\begin{tabular}{|c|c|c|}
\hline & Logic of tradition & $\begin{array}{l}\text { Logic of the transfer of } \\
\text { ideas }\end{array}$ \\
\hline $\begin{array}{l}\text { Understanding of } \\
\text { change }\end{array}$ & $\begin{array}{l}\text { Incremental change } \\
\text { (independence) }\end{array}$ & $\begin{array}{l}\text { Mutual fertilization } \\
\text { (interdependence) }\end{array}$ \\
\hline Level of analysis & Macro-level & Micro-level \\
\hline $\begin{array}{l}\text { Epistemological } \\
\text { approach }\end{array}$ & Deductive & Inductive \\
\hline Logic of inference & Ideal-typical narrative & $\begin{array}{l}\text { Historical-empirical } \\
\text { narrative based on } \\
\text { primary sources }\end{array}$ \\
\hline Focus of interest & National paths & Road junctions \\
\hline
\end{tabular}

The rest of this book is organized as follows. In the introduction, we present the administrative traditions of Germany, France and the USA as a conceptual map in comparative Public Administration. We then turn to our analytical approach of the transfer of ideas and demonstrate how we apply it to the history of administrative traditions. The following three chapters employ this approach to analyze our three cases, namely the transfer of ideas from Germany and France to the USA, the transfer of ideas from the USA to Germany, and finally, the transfer of ideas from the USA to France. In a comparative analysis of the findings, we discuss the question of 
whether Public Administration in Germany, France and the USA is primarily dominated by traditional flavors or hybrid traditions. We conclude this study with a glance into administrative praxis and what we can learn from the history of ideas and the analysis of the transfer-of-ideas to make administrative theory more realistic and administrative practice more successful.

\section{NOTE}

1. Public Administration with capital letters is used to refer to the academic discipline, whereas public administration with lower case letters is used to refer to administrative practice. 